\title{
The Role of National Industrial Court in Sustaining Harmony in Nigerian Health Sector: A Case of University of Abuja Teaching Hospital
}

\author{
Ifeanyichukwu Ojeka Ukonu ${ }^{1} \&$ Gideon A. Emerole ${ }^{2}$ \\ ${ }^{1}$ Human Resource Management Department, College of Management Sciences, Michael Okpara University of \\ Agriculture, Umudike, Nigeria \\ ${ }^{2}$ Business Administrative Department, College of Management Sciences, Michael Okpara University of \\ Agriculture, Umudike, Nigeria \\ Correspondence: Ifeanyichukwu Ojeka Ukonu, Human Resource Management Department, College of \\ Management Sciences, Michael Okpara University of Agriculture, Umudike, Nigeria. Tel: 234-815-656-2711. \\ E-mail: bobify@yahoo.com
}

Received: September 4, 2015

Accepted: December 12, 2015 Online Published: February 25, 2016

doi:10.5539/jms.v6n1p171

URL: http://dx.doi.org/10.5539/jms.v6n1p171

\begin{abstract}
Recently, Nigerian health sector especially the hospitals has been enervated by grievances, antagonism, unpleasantness, dissension, and apprehension. Unfortunately, the industry involved in ensuring workers' healthcare and that of the populace has experienced tempestuous times. Slyly, issues whose pedigrees could be traced to superiority, autonomy, compensation schemes and other conditions of service gradually meandered into the public health sector leading to health workers and non-health workers being at loggerhead with one another. As such, the serenity and harmony once witnessed in government hospitals have been jumbled by incoherent differences of various groups in the hospital. This paper therefore proposes to examine the causes of disputes at the University of Abuja Teaching Hospital; what has been done, and what needs to be done by all and sundry and more especially, the role National Industrial Court (NIC) has played in sustaining harmony in Nigerian health sector. Also, it will examine the role National industrial Court has previously played and can still play futuristically to enhance and sustain the desired industrial harmony in University of Abuja Teaching Hospital, the entire health sector and other sectors of the economy.
\end{abstract}

Keywords: organisational harmony, National Industrial Court, UATH, health sector

\section{Introduction}

In recent times, Government owned hospitals in Nigeria have experience 'wear' and 'tear' as they carry out their duties. In fact, the Nigerian health sector has been enervated by grievances, acrimony, conflict and apprehension (Ajayi, 2013). Sadly, the industry involved in ensuring the health of the workers and the entire populace has experienced turbulent times. Subtly, issues whose pedigrees could be traced to superiority, autonomy, compensation schemes and other conditions of service gradually meandered into Nigerian public health sector leading to health workers and non-workers being at loggerhead with one another. As such, the serenity and harmony once witnessed in the government hospitals have been jumbled by incoherent differences of various groups in the hospital.

Actually, the health sector is an open system made of different professionals each playing focal roles in operational existence of any health institution and the entire health sector. Strikes in Nigerian health sector have become endemic (Ajayi, 2013) and consequently, is becoming a clog in the wheel of the desired growth and development in all facets of Nigeria life, especially in the health sector. In other words, conflicts among different professional groups in the health sector are likened to cancerous wounds proving difficult to heal. Unceremoniously, the cirques keep deepening and as such are gravely affecting the smooth running of the hospitals. Hence, these conflicts have trickled down to unremitting strikes and other industrial actions. Although, conflicts are inevitable in an organisation, as Mullins (2005) proposed, they still occur even if organisations have taken great care to try and avoid it. These conflicts when not properly handled had escalated to industrial disputes.In this regards, the aggrieved parties in the health sector in a bid to resolve their disputes have resorted to strikes and litigations to 
drive home their points and grievances. These distortionshave not only adversely affectedthe health sector, other sectors in the economy and the society at large but have also ruptured the once harmonious scenario ostensible in hospitals. Despite Government's effort to appease and ensure harmony, peaceful and smooth running of different arms of the Health sector, there has been persistent distrust and antagonism between different groups. At various times, the harmony of the hospital has been truncated by incessant strike action resulting from compensation system, remuneration, to autonomy, conditions of service, leadership, and supremacy in the sector. Therefore, industrial harmony is paramount to industrial growth and sustenance. Suffice to say therefore that, the importance of harmony in the health sector cannot be overemphasised. Accordingly, the need to maintain an idyllic working environment in Nigerian hospitals and the role of the National Industrial Court in settling labour disputes remain a superlative option in situations where the aggrieved parties have decided to make the workplace a war zone. It therefore becomes appropriate to deal with issues that might lead to disputes and could predispose the sector to acrimony among different professional groups. Therefore, setting up the National Industrial Court (NIC) as the highest appellant court in promoting and sustaining harmony in the Health sector is a welcome development.

University of Abuja Teaching Hospital is a referral tertiary hospital that covers the north central geopolitical zone of the nation and its environs viz.: Kogi, Benue, Niger, Plateau, Nasarawa, and Kwara state respectively. The teaching hospital comprises consultants in different fields of medicine, medical officers, resident doctors under training, nurses, Pharmacists, physiotherapists, Laboratory Technicians, Dental Technicians, Nutritionists, and Community Health Workers and other supporting staff. There has been brain drain in the health sector among clinical staff, although highly reduced now as a result of improvement in terms and conditions of service. It is indisputably dreadful that professionals in this sector should embark on indefinite strikes in such a referral hospital with a wide coverage and where a reasonable, high number of workers are beneficiaries of the National Health Insurance Scheme (NHIS).In other words, harmony in the health sector, indirectly aids to the maintenance of a healthy workforce. Hence, the National Industrial Court (NIC) has been given the constitutional and judicial right to ensure that conflicts and disputes in organisations are resolved to sustain harmony. Consequently, the National Industrial Court among others has played either Advisory role or adjudicative role at one time or the other to ensure the sustainability of harmony among different professions at the University of Abuja Teaching Hospital. Additionally, NIC has also ensured harmony among different groups by providing adequate interpretation of status, awards, judgements, and rulings.

This paper therefore proposes to examine the role National Industrial Court (NIC) has played in sustaining harmony in Nigeria health sector. Also, it will examine the role National industrial Court has previously played and can still play futuristically to enhance the desired industrial harmony in University of Abuja Teaching Hospital, the entire health sector and other sectors of the economy.

\section{Review of Related Literature}

Industrial Relations (IR) is a multidisciplinary field that studies employment relationship and covers the relationship in employment andinstitutions associated with it (Dahida \& Adekeye, 2013). It deals with either the relationship between the state, employers and workers or between occupational organisations themselves. Furthermore, it is concerned with a complex of power relationship and power sharing; the economic and other decisions which emanate from employment (Okoh, 2005). Industrial Relations is three faceted, namely: science building; problem solving, and ethical, (Adejumo 2010). Adejumo further posited that IR is part of the social sciences, which seeks to understand the employment relationship and its institutions through high-quality and rigorous research. Ideally, the concept seeks to design policies and institutions to help the employment relationship work well.

Kale (2011) stated that in any ideal Industrial Relations, great emphasis is placed on the attainment of industrial harmony in order to create an environment conducive for the realisation of individual and organization goals and objectives. Adejumo (2010) in his speech on "NIC and harmony in universities" advocates that the imperative for promoting industrial harmony and having a successful or mutually beneficial relationship between employer and employee is anchored on effective communication between them. Essentially, this takes place in form of discussions, and covers areas like pay and bonuses, work schedules and environment, disputes and grievances, health and safety, etc. He asserted that when employees are not happy with working conditions, it frequently leads to high labour turnover, bad time keeping; high level of absenteeism and sometimes leads to strikes and litigations. In other words, if grievances are not effectively or amicably resolved, it will have ripple effects on the organisation, alongside the socio-economic aspects of the nation. This invariably will hamper adequate economic growth and development. 


\subsection{Industrial Dispute}

Conventionally, disputes mean difference or disagreement of strife over some issues between an employer or management and workers or labour unions, over pay and other working conditions and can result in industrial actions such as strike.Prahalad (2015) defined industrial dispute as a conflict or difference of opinion between management and workers on the terms of employment. It is a disagreement between an employer and employees' representative; According to Industrial Dispute Act 1947 the term Industrial dispute means any dispute or difference between employers and employers, or between employers and workmen, or between workmen and workmen, which is connected with the employment or non-employment or the terms of employment or with the conditions of labour, of any person (Chand, 2015; Prahalad, 2015).

The National Industrial Court of Nigeria (NICN) in Section 37 (1)of the Trade Dispute Act of 1976 defined dispute to mean "any dispute between employers and workers or between workers and workers which is concerned with employment or non-employment or terms of employment and physical conditions of work of any person" (Kale, 2011). By the same token, Section 45 of National Industrial Court Act of 2006 provides the definition of a "trade dispute" as any dispute between their representative organisations and federations which is connected with the employment, non-employment, termination, or suspension or duties of any worker. The section also went further to define dispute to mean a "dispute" between the afore- mentioned parties; and is connected with the terms and conditions of employment or the physical conditions in which any worker is required to work, and as well as with the conclusion or variation of a collective agreement; and any alleged dispute (Targema, 2013).Whereas Cambridge Dictionary online defined industrial dispute as a disagreement between workers and management over pay, workingconditions, hours of work, etc., especially one that includesstrikes (workersrefusing to work). Mostly, industrial disputes in UATH come from National bodies of the respective trade unions. Dispute Management according to H.J. Elliot and Associate PTY Ltd. consists of policies, procedures, systems, skills and resources to enable organisations to successfully manage disputes. According them, the management of disputes covers disputes that occur within an organisation, such as workplace disputes, employer/employee negotiations, harassment, and, disputes that involve an organisation and an external third party, such as regulators, customers, trading partners and the community.

\subsection{Types of Dispute in University of Abuja Teaching Hospital}

The International Labour Organisation (ILO) has classified the industrial disputes into two main types (Chand, 2015). We shall discuss the types of dispute in UATH along ILO's classification. They are: Interest Dispute and Grievance or Right Disputes.

\subsubsection{Interest Disputes}

These disputes are also called 'economic disputes'. Such types of disputes according to Chand (2015) arise out of terms and conditions of employment either out of the claims made by the employees or offers given by the employers. Such demands or offers are generally made with a view to arrive at a collective agreement. Examples of interest disputes are claims for wages and bonus, job security, fringe benefits, etc. There has been so much acrimony in UATH about remuneration and compensation package. Discrimination in salary scales and allowances among interdisciplinary group and skipping of a grade level are among the causes of conflicts in the hospital. In the civil service for instance, there is no grade level 11, an employee moves from grade level 10 to 12. In the hospitals, other workers apart from doctors skip grade level 10 that is they move from 9 to 11 . This is one of the issues raised by resident doctors in the on-going strike (as at the time of this report August 2015).

\subsubsection{Grievance or Right Disputes}

Grievance or right disputes arise out of application or interpretation of existing agreements or contracts between the employees and the management. They relate either to individual worker or a group of workers in the same group. In UATH, the issue of autonomy in the laboratory and leadership position has raised a lot of dust. The Laboratory Scientists are agitating for autonomy in the laboratory. Ab-initio, a clinical haematologist endorses any result from the laboratory before it is sent out. Also, the Joint Health Staff Union JOHESU are asking for assuming leading roles in the hospital like being Chief Medical Officer of the Hospital and Chief Medical Advisory Committee.

\subsection{Industrial Harmony}

Having discussed issues that have truncated the harmony that exist in Public health sector, it is pertinent to examine what harmony means. Industrial Harmony therefore, is the ideal state of peace wherein workers engaged in production of goods and services feel content, thereby are propelled to give the best of their talents and talent potentials for the development and progress of the organisation (nairaprojects $/ 313 / \mathrm{html}$ ). Adejumo 
(2010) defined the concept 'Industrial Harmony' as a situation where the employees and management cooperate willingly for the organisation's corporate objectives. Also, it refers to a state of relatively peace in the organisation, which involves absence of strike and distrust among work groups or unions, peaceful relationship between unions and management of the organisation as well as employee's positive perception of his or her contribution as a participant not as subject within the organisation (Bassey et al., 2012).

Harmonious industrial relations refers to an industrial environment where workers along with their union and management understand and accept each other as partners in progress; that a cooperative attitude is mutually beneficial in terms of output, performance and rewards (Osawonyi \& Ugiagbe, 2013). They further posit that industrial harmony does not assume absence of conflict rather, effective and proactive collective agreements, and grievance procedure that can prevent conflicts from transforming into a crisis.In Malaysia, the Code of Conduct for Industrial Harmony is an agreement made between the Ministry of Human Resources and the Malaysian Council of Employer Organisations. Its aim is to lay down principles and guidelines to employers and the workers on the practice of Industrial Relations for reaching Industrial Harmony (www.amco.org.my/n-archieves/CodeOfConductforIndustrialHarmony.pdf). Notably, Industrial court is not limited to Nigeria or Malaysia. There are similar Industrial/Labour Courts in other countries like Trinidad and Tobago, Ghana, Tanzania, India, Ireland, South Africa and other countries.

Thus, we can refer to Industrial harmony in the health sector as a state of peaceful existence and agreement among the different professionals. It also can refer to a state of affairs where the employees and management cooperate willingly in order to achieve corporate goals and objectives. It is noteworthy to assert that Industrial harmony does not portray a state of no conflict and dispute among professionals in the health sector neither does it depict a scenario where everything is homogenous in terms of agreement or decision. Just as harmonisation in music usually sounds pleasant to the ear when there is a balance between the consonant and dissonant sounds, that is how the different groups have to make conscientious effort to work together in harmony. It is instructive to state here that is near impossible to find a human setting devoid of disagreements and disputes of varying magnitudes. However, National Industrial Court in collaboration with the management of UATH is doing all within the ambit of their power to sustain Harmony in the hospital.

\subsection{Ways Employees Express Dissatisfaction in the Health Sector As Seen In (UATH)}

Employees may express dissatisfaction in their organisation either formally or informally. A typical example of formal expression of grievance, conflict or dispute is known as a strike. Others are: Lock-out, and picketing. Informal industrial conflict on the other hand often comprises individual or small group actions ranging from purposeful negligence to sabotage.

\subsubsection{Strike}

Section 48(1) of the Trade Disputes Act, defines a strike as the cessation of work by a body of persons employed acting in combination, or a concerted refusal under a common understanding of any number of persons employed to continue to work for an employer in consequence of a dispute, done as a means of compelling their employer or person or body of persons employed, to accept or not to accept terms of employment and physical conditions of work. Sympathy strike as the name goes takes place where a union goes on strike in solidarity with another union who is on strike. Really, it is a support strike. As put by Owoye, Okorie, Agomo (2013) where sympathy strikes are concerned, the crux of the issue is to decide whether workers may declare a strike for occupational, trade union or social and economic motives which do not affect them in a direct and immediate manner.

\subsubsection{Lock-out}

Lock outis referred to as temporary stoppage of work or denial of employment initiated by the management of an organisation in a labour dispute. Lock out as defined by Section 48 of the Trade Disputes Act means the closing of a place of employment, or the suspension of work, or the refusal by an employer to continue to employ any number of persons employed by him in consequence of a dispute, done with a view too compelling those persons, or to aid another employer in compelling persons employed by him, to accept terms of employment and physical conditions of work. It may also mean the temporary refusal of an employer to furnish work as a result of an industrial or labour dispute between the employer and the workers.

Normally, management is supposed to take the initiative from the definitions above. On the contrary, the striking unions usually the non-doctors in University of Abuja Teaching Hospital lock up the ward, store or where equipment are kept away from doctors. This is to prevent even the slightest skeletal jobs that would otherwise have been provided by the doctors. 


\subsubsection{Picketing}

Picket is a form of protest in which people called picketers (Dictionary.reference.com) assemble outside a place of work or location where an event is taking place. Often, this is done in an attempt to dissuade others from going in ("crossing the picket line"), but it can also be done to draw public attention to a cause. Ordinarily, Picketers endeavour to be non-violent. It is instructive to state here that the protest is all about barring people from entering the building or offices.

\subsubsection{OthersWays}

Other ways workers at University of Abuja Teaching Hospital had expressed dissatisfaction is through direct criticism and verbal attacks against management of the hospital. However, sequel to the recent NARD strike, resident doctors have accused their senior colleagues of being insensitive of their challenges. Hence, through informal and/or formal counselling different unions have at one time or the other advised management of the hospital on how to resolve conflicts of interest. Another form is by secretly complaining to a third and influential party about their grievances. Also, sabotage has been observed; where striking nurses, Laboratory scientists and pharmacists lock up their offices especially, the laboratory and the wards to prevent doctors from working.

\subsection{National Industrial Court (NIC)}

The National Industrial Court (NIC) was established in 1976 (which later became the Trade Disputes Act (TDA) Cap T8 Laws of the Federation of Nigeria, 2004), pursuant to the Trade Disputes Decree No. 7 of that year to take care of trade disputes between employers and employees, workers and workers, trade unions and workers (Adeoti, 2009), but it actually took off two years later in 1978 (Adejumo, 2011). The statutory mechanism for the settlement of trade disputes was found in the Trade Disputes (Arbitration and Enquiry) Actfirst enacted in 1941.The said Act empowered the Minister of Labour to intervene by means of conciliation, formal inquiry and arbitration where negotiation had failed. At this juncture, it is pertinent to note the two notable features of the Act which might be considered as its draw back. First, the parties had absolute discretion to decide whether or not they would avail themselves of the machinery provided. Hence, the Minister could not compel them to accept his intervention (Adejumo, 2007) but could only appoint a conciliator upon the application of one of the parties; whereas he needed the consent of both parties to set up an arbitration tribunal. Secondly, the Act did not make provision for permanent institutions whereby disputing parties could go for the settlement of their labour disputes. Alternatively, an arbitration panel which is an ad hoc committee were to be set up for a particular dispute and once it gave its decisions, the case is closed.

The NIC under Trade Dispute Act (TDA) as amended by the Trade Disputes (Amendment) Act 1992 (Decree No.47 of 1992) was generally structured in a regimented and compartmentalised labour disputes resolution regime with circumscribed ministerial discretion. In the majority of cases, the jurisdiction of the NIC was activated only upon a referral from the Minister of Labour. Indeed, according to Rule 13 of the National Industrial Court Rules, cap T8 Laws of the Federation of Nigeria, 2004, a trade dispute "shall be commenced by reference from the Minister". The circle of trade disputes resolution mechanisms in Nigeria will be incomplete without going through the role of the NIC (Adejumo, 2010).

\subsubsection{NIC Act 2006 and Beyond}

The aftermath of the Conference on "Nigerian Industrial Disputes Resolution System: Challenges and Prospects for the National Industrial Court"chaired by Hon. Justice M.L. Uwais, the then former Chief Justice of Nigeria, between $5^{\text {th }}$-7th of November 2003, led to the passage of the NIC Bill by the National Assembly in June, 2006 which was then assented to by President OlusegunObasanjo and thus became an Act of the National Assembly. Adejumo (2010) stated that the NIC Act, 2006, came into force on June 14 2006. The NIC Act establishes the National Industrial Court as a superior court of record and confers jurisdiction on the Court with respect to labour and industrial relations matters. Given the existence of the NIC since 1976, he restated that it was more appropriate to talk of the NIC Act as re-establishing the National Industrial Court more so when the provisions of the NIC Act merely props the Court to give it pre-eminence in the resolution of labour disputes.

The Act states that There shall be a National Industrial Court for Nigeria (in this part of this Act referred to as "the Court") which shall have such jurisdiction and powers as are conferred on it by this or any other Act with respect to the settlement of trade disputes, the interpretation of collective agreements and matters connected therewith.

According to Kanyip (2010), before June 14, 2006 when the NIC Act 2006 became operative, the NIC could only deal with trade disputes, which by definition referred to only collective labour disputes. Prior to the enactment of the NIC Act, and especially given the definition of the term trade dispute in section 47(1) of the 
TDA, the NIC generally ruled that only registered trade unions had the locus to come before it on behalf of workers (Adejumo, 2010). As regards to this, associations that were not registered as trade unions but were however registered under some other law had the capacity to sue and be sued were denied the right of audience at the NIC. Section 7(1) of the National Industrial Court Act provides that the court shall have and exercise jurisdiction in several labour related courses and matters. Kanyip (2010) stated that presently, the manner in which section 7 of the NIC Act is implied has taken the NIC out of the purview of the individual/collective dispute divide. According to him, under section 7 of the NIC Act, jurisdiction of the court is subject based, not person based. This means that while individuals may not be able to ventilate their grievances under Part I of the TDA, they may nevertheless directly approach the NIC to have those grievances redressed.

Conversely, the 1999 constitution Third Alteration Act 2011 confers on NIC all powers of High Court. This Act expanded the pre-existing limited jurisdiction of the NIC by acquiring additional powers. The court by an indefensible lapse of legislative judgement was made, with little exception, a court of last resort, a court of first and last resort whose decision cannot be appealed (Ogunye, 2014).

\subsection{Trade Disputes Resolution Mechanisms under the Trade Dispute ACT (TDA)}

The Trade Dispute Act, (Cap T8 Laws of the Federation of Nigeria 2010) acknowledges that trade disputes are inevitable in industrial organisations. Part 1 of the TDA which consists of sections 1-18 was originally intended to regulate trade disputes amicably. Section 4(1) of the Act stipulates that the first step in resolving disputes is for both the workers and the management to enter into collective bargaining toward resolving any crisis internally. Where the attempt to settle the dispute provided in subsection (1) of section 4 fails, Subsection (2) of section 4 of the Act specifies that the parties shall within seven days of the failure meet together or their representatives under the presidency of a mediator mutually agreed upon and appointed by or on behalf of the parties, with a view to the amicable settlement of the dispute.

The Act states that if within seven days of the date on which a mediator is appointed the dispute is not settled, the dispute shall be reported to the Minister (Hon. Minister of Employment, Labour and Productivity) by or on behalf of either of the parties within three days of the end of the seven days. The Minister is statutorily empowered to give time to the parties to the dispute within which they in compliance with the provisions of sections of 4 and 6 take steps to resolve the dispute. The law states that if the mediation fails, the issue should be taken to a Conciliator appointed by the Minister to resolve the dispute between the parties. The Act further stipulates that if the dispute is not resolved, the Conciliator shall within seven days forward his report to the Minister. The Minister shall therefore within fourteen days of the receipt of such report refer the dispute for settlement to the Industrial Arbitration Panel (IAP) where an award would be given. The award, involves the signing of a communiqué after an agreement that must be binding on the employer and the workers. On receipt of a copy of the award, the Minister shall cause it to be given to the parties or their representatives. The award is then published in the manner deemed fit by the Minister. If there were no objections the award is then confirmed. The problem with IAP is that the awards of the IAP are not binding and there is no legal process to enforce such awards. As a result of this, employers deliberately pay less or no attention to the awards of the panel, thus the efficacy of the tribunal is reduced (Anyim, Francis, \&Odogwu, 2012; Agomo, 2000; Agomo, 2011; Adejumo 2010).

If notice of objection is given to the Minister, the dispute is then referred to the NIC. This provision of the law has been altered by section 7(4) of NICA, 2006. Under this section the parties have the right to apply directly to the Court. It is important to note here that section 53 of NICA provides that other provisions of the TDA shall be construed with such modification as may be necessary to bring them into conformity with the provisions of the Act. Under Section 32 and 33 of the TDA, the minister is empowered to constitute a board of inquiry. This is another mechanism for the resolution of trade disputes. Under Section 32(1), of the TDA, the board is statutorily expected to only inquire into the causes and circumstances of the trade dispute in question and report to the Minister. But the role of the Minister in the ultimate resolution of disputes under the above provisions of the TDA is very significant and weighty.

According to Kanyip (2010), there are certain types of disputes that are often dealt with procedurally different because they tend to be more sensitive or complex or because their outcomes tend to affect many people, or because they involve considerations of principle(s) which have policy implications for the society at large. He further noted that if these disputes are not susceptible to settlement by mediation/conciliation, they tend to be dealt with by adjudication in the courts (given that courts, not arbitration, create precedent) and not by the less formal process of arbitration, unless the parties agree otherwise. Such disputes according to him are: discrimination and sexual harassment, retrenchment, organisational (i.e., trade union) rights, core labour rights 
and standards, and recognition disputes. Within the structure of the TDA, these species of disputes are generally treated as collective disputes and so treated as such, except for discrimination and sexual harassment complaints which are hardly pressed by victims under our labour jurisprudence.Notably, the TDA adds that if an issue arises as to the interpretation of the award, the minister or any party to the award may make an application to the National Industrial Court for a decision. The Act states that the decision of the Court is final (Adejumo, 2010; Ogunye, 2014).

\subsection{The Role of NIC in Sustaining Industrial Harmony}

National industrial court is a specialised labour court set up to deal with labour/industrial related matters. At this juncture, it is important to note that Labour courts are not peculiar to Nigeria, but are being established in several countries. Axiomatically, this is because the conventional courts and the system of law they administer, which is essentially based on common law principles are ill-suited for the challenges of modern economics and so can no longer adequately and timorously deal with labour related issues. Furthermore, labour issues are pure economic matters which require equitable approach rather than purely legalistic approach. Also, labour matters play a vital role in the development and growth of any nation thus; the court is empowered to decide industrial issues on application of both equitable and legal principle (Adejumo, 2007, 2010).However, setting up the National Industrial Court (NIC) as the highest appellant court in sustaining harmony in organisations including the Health sector is a welcome development. The court has both original and appellate jurisdiction in civil matters but it has no criminal jurisdiction except on matters of contempt of its orders (Adejumo, 2010). The law now, in addition, confers upon the NIC the exclusive adjudicating power on labour and Industrial Relations laws. The Act establishing the National Industrial Court of Nigeria instituted it as a specialised tribunal whose jurisdiction is solely and judiciously to the exclusion of all other courts, on matters relating to or connected with any labour, employment, trade unions, industrial relations disputes and matters arising from the workplace, conditions of service, including health, safety, welfare of labour, employees, workers and matters incidental thereto or connected therewith (Aderibigbe, 2014).

Therefore, the major role of Industrial Court is to promote and sustain industrial harmony. Others are to regulate the relations between employers and their employees; between the trade unions and employer organizations; and resolve disputes arising from these relations. The Court goes about mediating the boundaries of rights and obligations of employers and employees in accordance with equity, good conscience and the substantive merits of the dispute. Its primary objective therefore is to attain social justice by upholding fair work practices. For instance, during the hearing of Senior Staff Association of University Teaching Hospitals, Research Institutions and Associated Institutions (SSAUTHRIAI) and others verses Federal Ministry of Health and others, unreported Suit No. NIC/12/2000, the NIC had cause to stop professional associations in the health sector that were not registered as trade unions from further participation in the matter before the Court. The question was whether, given the general provision of section 7(1) (a) (i) of the NIC Act, these bodies could be denied access to the NIC even when the issue in dispute was a matter relating to labour. This means that such bodies would now be accorded a right of hearing, because the jurisdiction of the NIC is now subject based. Particularly, and going by section 7(1) (b) of the NIC Act, the NIC would equally have jurisdiction to hear any matter relating to the grant of any order to restrain any professional association, body or person from taking part in any strike or industrial action. This is because section 7(1) (b), as a provision, relates to any person or body. It is not restricted to trade unions or employers organizations alone. So if the issue is a strike, lock-out or industrial action, the NIC would have jurisdiction. All of this is however, subject to the caveat that the professional association or body in issue, not being a registered trade union, cannot claim the privileges and immunity from action that trade union enjoys when acting lawfully as trade unions (Kanyip, 2010).

Muru (2015) summarised the role of NIC in sustaining organisational harmony especially in the health sector under two headings. First is Advisory role and second role is Adjudication. The under-listed cases are a few of several instances where NIC has in her capacity participated actively in decision making in the Nigerian Health Sector, thereby stimulating embers of Industrial Harmony.In Federal Ministry of Health v. National Association of Nigerian Nurses and Midwives (Digest of Judgements of the National Industrial Court), application was made by the Applicant to NIC by means of originating summons for the interpretation of an Award summons for the interpretation of an Award made by IAP in disputes between both parties. Whereas the Applicant upheld that it had implemented the Award, The Respondent did not agree to it. The Respondent gave the Applicant an Ultimatum within which to implement the Award and threatened to go on nation-wide strike. Against this backdrop, the Applicant made an instantaneous application to National Industrial Court. National Industrial Court in granting the application, held that "a dispute is said to exist where there is a difference of opinion 
between both sides (employer and workers), as to how an Award by the IAP should be implemented..." (Tergema, 2013)

\subsection{The Role of NIC in Sustaining Industrial Harmony at UATH}

Over the past few years, university of Abuja has witnessed a lot of strikes. However, the incessant strikes witnessed by UATH over the past few years has reduced as NIC has been on top of the situation by ensuring a fair handling of cases that could not be handled internally within the hospital. It is instructive to state here that while some of the disputes are internally motivated within the hospital, some are external from a trade union's national body. However, no matter the angle from which the dispute is emanating from, as long as it could not be handled internally, NIC have not only played advisory and adjudicatory roles but also interpreting awards, status, judgment and rulings. From the inception of NIC, the court's contribution to national development and industrial harmony is immense. As a specialised Court, the National Industrial Court has often risen to the occasion to avert losses in the health sector, when called upon to do so (Tergema, 2013). For instance, in the case National Association of Nigerian Nurses and Midwives Vs. Medical Board, Nigerian Baptist Convention (Digest of Judgement of the National Industrial Court), the parties had dispute and the main issues raised were retirement benefits and industrial actions by workers. The disputing parties were referred to Industrial Arbitration Panel (IAP). The second item was later withdrawn by the Association having resolved the issue and workers resumed their normal duties. Then the IAP made its Award on the issue on retirement benefits comprising. The Association not satisfied with the Award made an appeal to National Industrial Court of Nigeria. The Court held that NIC can enforce implementation of the contents of a circular which both parties had agreed on to be made the judgment of the court. Hence, the dispute was put to rest.In the Joint Health Sector Unions (JOHESU) v. Federal Ministry of Health, Suit No: NICN/ABJ/238/2012 (Medical World Nigeria, 2014), the issues in dispute, which this Court had been asked to adjudicate on, were - Non-Skipping of salary CONHESS 10, National Health Bill, Consultancy \& Specialist Allowance and, Call/Shift and other professional allowances. The Court held in favour of JOHESU but the complainants for $10 \%$ of CONHESS for all eligible health professionals as administrative allowance was, therefore, uncalled for and so failed accordingly dismissed. The Court agreed on increase in call duty allowance. However, the claim for equality of treatment as regards call duty allowance was unfounded according to the court and so dismissed. Also, held by the Court was that the respondent had the right to direct that non-medically qualified health professional should not be appointed as Consultants in Federal Government Institutions, however, the directive that any such appointment previously made should be reverted immediately is invalid and hence unlawful. Consequently, all members of the complainant unions who were appointed previously as Consultants but whose appointments have now been reverted, the reversion of such appointment was thereby declared null and void and of no effect. They were thereby entitled to the payment of specialist allowance.

\subsubsection{Advisory Role}

When disputes are brought before a court most of the times whether arising as a result of friction between employees and employers or inter professional relationship, the court usually advises the parties involved to go and settle the case by way of resolving their differences. When the differences are resolved and settlement attained, the terms of settlement are thereby filed and adopted by the court as consent of judgement for the parties. In the case of UATH Vs. Joint Action Congress, National Association of Nigerian Nurses and Midwives, in Suit No. NICN/ABJ/28/2013, the court ruled that the parties should go back to the hospital and settle the case.

\subsubsection{Adjudication}

When parties fail to attain settlement as advised by the court, they proceed with trial of their case before the court. Each party presents its position before the court, and then the court strikes a balance by proffering decision that is best for resolving the conflict or disharmony in the circumstance. In case of professional rivalry between the pathologist and Laboratory scientist in UATH: when management of the hospital could not resolve the case, it was taking to Federal High Court and then to NIC. The Laboratory scientists cited the Asaba case where the court gave an injunction in favour of the Laboratory Scientist, but the court struck out the case. Currently, National Association of Resident Doctors (NARD) has been on strike over skipping of CONMESS 02 for doctors. The association rode on back of illegality of skipping approved for JOHESU by court injunction to request for their own skipping. This has been approved and NARD is awaiting cash backings before going back to work. However, the strike was suspended on towards the end of August, 2015. In the case of Joint Health Sector Union (JOHESU), Suit No. NICN/ABJ/238/2012, the court ruled in favour of JOHESU but the ruling is yet to be implemented by Government. 


\subsubsection{Interpretation and Application of Status, Awards, Judgments and Rulings}

The National Industrial Court also interprets status and rulings in a situation where parties are not cleared on some terms used in a status, award or ruling. NIC is involved in matters relating to the determination of any question as to the interpretation and application of the following in UATH:Collective agreement; award or order made by an arbitral tribunal in respect of a trade dispute or a trade union dispute; award or judgment of the court; term of settlement of any trade dispute; trade union dispute or employment dispute as may be recorded in a memorandum of settlement; trade union constitution, the constitution of an association of employers or any association relating to employment, labour, industrial relations or work place; dispute relating to or connected with trade disputes arising from payment or non-payment of salaries, wages, pensions, gratuities, allowances, benefits and any other entitlement of any employee, worker, political or public office holder, judicial officer or any civil or public servant in any part of the Federation and matters incidental thereto.

The Joint Health Sector Union went to court (NIC), alleging the displeasure about the appointment of only Medical doctors of Chief Medical Director,Chief Medical Advisory Committee and Deputy Chief Medical Advisory Committee, the court ruled that the position should be reserved for a medically qualified person. The contention was the definition of who "a medically qualified person" was. The court interpreted that a medically qualified person means a medical doctor. This ruling the NIC has brought calmness back to the hospital at the moment.

\section{Conclusion}

In bringing this discourse to a conclusion, it is pertinent to state that the role of National Industrial Court in sustaining industrial/organisational harmony especially in the health sector cannot be overemphasised. Basically, industrial harmony is requisite to economic growth, development and industrial advancement in any economy. As such, whether in the instances of inter union disputes or in the demesnes of employee and employer relationship, NIC has risen to the challenge to extinguish the rising tensions that might have escalated out of proportion in UATH as well as other institutions.

Apparently, the National Industrial Court is the appropriate arbiter as far as industrial relations is concerned. Notably, the role of National Industrial Court in sustaining industrial harmony across the nation is enjoying all sorts of transition. This is predicated by the fact that the law continues its metamorphosis as a result of the dynamic nature of the workforce resulting from social, economic and technologies changes both nationally and worldwide. In addition, the 1999 constitution Third Alteration Act 2011 has made allowance for individuals to bring their cases directly to NIC instead of the previous process where the issue had to pass through the minister of Labour. Hence, within the ambit of relevant laws, the law has empowered the NIC to bring justices to disputants that need it. At this juncture, it is important to state that it is near impossible to find a human setting devoid of disagreements and disputes, of varying magnitudes. However, National Industrial Court is poised to ensuring that harmony is sustained in the health sector and all sectors of the economy.

\section{Acknowledgement}

The authors would like to express their gratitude to Barrister Muru Jonathan, for his important contributions to this article.

\section{References}

Adejumo, B. A. (2007). The Role of the Judiciary in Industrial Harmony. Being commentary delivered at 2007 All Nigeria Judges' Conference Organized by The National Judicial Instituteat LadiKwali Hall of the Abuja Sheraton Hotel and Towers, Abuja, FCT.

Adejumo, B. A. (2009). Effect of Industrial Disputes Resolution on Investment in Africa. Being paper Delivered at Lagoon Restaurant Organised by: National Conflict Mediation Group on President of the National Industrial Court. By Hon. Justice BabatundeAdeniranAdejumo (OFR).

Adejumo, B. A. (2010). NIC and Harmony in Universities. Retrieved from news.onlinenigeria.com/.../22021-nic-and-nic-harmony-in-universities

Adejumo, B. A. (2011). The National Industrial Court Of Nigeria: Past, Present and Future. Being A Paper Delivered At The Refresher Course Organised For Judicial Officers Of Between 3-5 Years Post Appointment By The National Judicial Institute, Abuja At The OtutuObaseki Auditorium, National Judicial Institute.

Adejumo, B. A. (2013). Inaugural speech by President of National Industrial Court of Nigeria at the Inaugural siting of the Makurdi Division of the Court on 4th of February, 2013 at Makurdi, Benue State, Nigeria. 
Adeoti, F. (2009). National Industrial Court: Our journey From Obscurity-Justice Adejumo, President, Furtune News.

Aderibigbe, S. (2014). Labour Dispute Resolution in Nigeria. Retrieved from https//:www.academia.edu/9259118/Labour_Dispute_Resolution_In_Nigeria

Adesina, H. (2009). Fundamentals of Management. Lagos: Mangroove Books.

Adomi, E. E., \& Anie, S. O. (2006) Conflict Management in Nigerian University Libraries. Library Management, 27(8), 520-530. http://dx.doi.org/10.1108/01435120610686098

Agbi, S. (2013). Conflict Management and Collective Bargaining in Workplace: A case study of the University of Abuja Teaching Hospital Gwagwalada Abuja. Being a Paper Presented at Workshop on Labour-Management Relations at the University of Abuja Teaching Hospital Conference Hall.

Agomo, C. (2000). 'Nigeria', in Labour Law and Industrial Relations in the International Encyclopaedia of Law (Prof. Dr.Blanpain ed.).

Agomo, C. (2011). Nigerian Employment and Labour Relations; Law and Practice. Lagos: Concept Publications Limited.

Ajayi, F. (2013). Emerging Trends of Industrial Relations in Health Sector: The Way Forward. Being Excerpts from Prof. Femi Ajayi's Guest Lecture, Institute of Health Service Administrators of Nigeria 27th National Conference/Annual General Meeting Neuropsychiatric Hospital, Aro, Abeokuta. Retrieved from nigeriaworld.com/columnist/ajayi120313.html on 09/08/2015

Anyim, C. F., Chidi, O. C., \& Ogunyomi, O. P. (2012). Trade Dispute and Settlement Mechanism Nigeria: A Critical Analysis. Interdisciplinary Journal of Research in Business, 2(2), 1-8.

Atilola, B., Dugeri, M. (2012). National Industrial Court of Nigeria and the Proposed Alternative Dispute Resolution Centre: A Road Map. Article on ADR for National Industrial Court.

Barret, W., Covali, B., \& Domnic, S. (2005). Industrial Relations and Worker Society, Aspect of Interaction. London: Macmillan.

Bassey, A. O., Ojua, T. A., Archibong, E. P., \& Bassey, U. A. (2012). The Impact of Inter-Union Conflicts on Industrial Harmony: The Case of Tertiary Institution in Cross River State. Nigeria, Malayasian Journal of Society and Space, 8(4), 33-39.

Burton, J. (1990). Conflict: Resolution and Prevention. New York: St Martin's Press.

Cambridge Dictionary online. from dictionary.cambridge.org/dictionary/business-english/Idustrial-Dispute

Chand, S. (2015). Industrial Disputes, Definition, Forms and Types. Retrieved from www.yourarticlelibrary.com/Industries/Industrial-disputes-definition-froms-and-types/35453/

Dahida, D. P., \& Adekeye, J. A. (2013). A Comparative Analysis of Trade Disputes Settlement in Nigerian Public and Private Universities. Journal of Law, Policy and Globalization, 18, 60-68.

Hatch, M. J. (2006). Organization Theory: Modern, Symbolic and Post-Modern Perspectives. Oxford: Oxford University Press.

ILO Freedom of Association. (2006). Digest of decisions and principles of the Freedom of Association Committee of the Governing Body of the ILO, Geneva, International Labour Office, Fifth (revised) edition.

James, R. (2013). The Proper Role and Jurisdiction of the Industrial Court. Retrieved from http://kenyalaw.org/kenyalawblog/the-proper-role-and-jurisdiction-of-the-industrial-court/\#sthash.ukQzHq YQ.dpuf

Jonathan, P. S. (2003). Industrial Conflict CBE Faculty in the column of Business Focus of Manila Bulletin.

Kale, K. L. (2011). An Examination of the Laws and Procedures Regulating Trade Dispute in Nigeria. Being Long Essay On Common Law Submitted To Faculty Of Law, University Of Ilorin, Ilorin, Nigeria.

Kanyip, B. B. (2010). The National Industrial Court of Nigeria: The Future of Employment/Labour Disputes Resolution by Hon. Justice Benedict Bakwaph KANYIP, Presiding Judge, National Industrial Court Lagos Division.

Medical World Nigeria. (2014). Being National Industrial Court of Nigeria Ruling between JOHESU and The Federal Ministry of Health. Retrieved from www.medicalworldnigeria.com 
Morrill, C., \& Thomas, C. K. (1992). Organizational Conflict as Disputing Process: The Problem of Social Escalation. http://dx.doi.org/10.1111/j.1468-2958.1992.tb00558.x

Mullins, L. J. (2005). Management and Organisational Behaviour. Harlow, FT Prentice Hall an imprint of Pearson Education.

Muru, J. (2015). The Role of National Industrial in Sustaining Organisational Harmony in the Health Sector. Being an Unpublished Note.

Ogunye, J. (2014). National Industrial Court and Judicial Absolutism in Nigeria. Premium Times.

Okoh, O. A. (2005). Personnel and Human Resources Management in Nigeria. Lagos: AMFITOP.

Onyearu, A. O. (2015). The National Industrial Court: Regulating Dispute Resolution in Labour Relations In Nigeria. Retrieved from www.gamji.com/article8000/NEWS8437.htm

Osamwonyi, I. O., \& Ugiagbe, E. O. (2013). Harmonious Industrial Relations as a Panacea for ailing Enterprises in Nigeria. Journal of Asian Scientific Research, 3(3), 229-246.

Owoye, I. S., Okorie, L.U., \& Agomo, C. K. (2013). A seminar presentation on the Right to strike: a comparative analysis. Faculty of Law School of Postgraduate Studies University of Lagos (CIL 805). Uploaded by LazurusOkorie.

Prahalad. (2015). Industrial Disputes. Retrieved from www.naukrihub.com/unauthorized/Industrial-disputes.html

Robert, P. (2015). Theories of Industrial Conflict. Retrieved from http://www.ehow.com/info_8567695_theories-industrial-conflict.html

Tairu, N. (2001). Liberalising the Industrial Disputes Resolution Processes in Nigeria: Option and Recommendations. A paper presentation at a Two Day Advocacy Workshop on the Review of Trade Disputes Resolution Mechanism in Nigeria organized by the National Association of Democratic Lawyers (NADL) from June 20-21, 2001 at Circular Hotel, Ilorin, Kwara State.

Tergema, J. I. (2013). Legal Means of Dispute Management and the Role of National Industrial Court in Sustaining Industrial Harmony in the Health Sector. Being a Paper Presented at Workshop on Labour-Management Relations at the University of Abuja Teaching Hospital Conference Hall.

The Role of Human Resource in Promoting Industrial Harmony. Retrieved from nairaproject.com/projects $/ 313 \mathrm{html}$

\section{Copyrights}

Copyright for this article is retained by the author(s), with first publication rights granted to the journal.

This is an open-access article distributed under the terms and conditions of the Creative Commons Attribution license (http://creativecommons.org/licenses/by/3.0/). 